\title{
Gemar Makan Ikan untuk Kecerdasan Anak Sekolah di MTS Al-Maidar Pandan Kabupaten Tapanuli Tengah
}

\author{
Emma Suri Yanti Siregar ${ }^{1}$, Tengku Muhammad Ghazali², Rosmasita Rosmasita ${ }^{3}$, \\ Dian Fitria Manurung ${ }^{2}$, Juliana Pebrina Siburian1', Insaniah Rahimah11, Sonia Ginatha1, \\ Ahriansah Rao', Esi Wahyuni', Sahraini Sahraini' \\ ${ }^{1}$ Departemen Sosial Ekonomi Perikanan, 2Departemen Akuakultur, ${ }^{3}$ Departemen Teknologi Penangkapan Ikan, \\ Sekolah Tinggi Perikanan dan Kelautan Matauli \\ Jl. KH. Dewantara No.1 Tapanuli Tengah, 22538, Indonesia
}

\author{
ARTICLE INFO \\ Received: 2021-01-16 \\ Revised: 2021-03-04 \\ Accepted: 2021-06-10 \\ Keywords: \\ Education, Fish \\ consumption, Nutrition, \\ Younger generation
}

\begin{abstract}
Indonesia is a maritime country that has many marine natural resources. Central Tapanuli Regency has a position close to the sea. Even though fish has a high protein content with amino acids, students or young people still like to eat fish a little. So it is necessary to provide information and at the same time invite the younger generation to like to eat fish to increase their intelligence. This community service activity was carried out at MTS Al-Maidar Pandan, Pandan District, Central Tapanuli Regency. The method of implementing this service activity is done by providing socialization about the importance of eating fish for MTS Al Maidar students. The outcomes achieved are increasing students' knowledge about the benefits of fish consumption and the nutritional value contained in fish as well as providing students' understanding with the knowledge to be able to distinguish between fish that are suitable for daily consumption or not.
\end{abstract}

(C)2021 Published by University of Merdeka Malang. This is an open access article distributed under the CC BY-SA 4.0 license (https://creativecommons.org/licenses/by-sa/4.0/)

How to cite: Siregar, E. S. Y., Ghazali, T. M., Rosmasita, R., Fitria, D., Siburian, J. P., Rahimah, I., Ginatha, S., Rao, A., Wahyuni, E., \& Sahraini, S. (2021). Gemar Makan Ikan untuk Kecerdasan Anak Sekolah di MTS Al-Maidar Pandan Kabupaten Tapanuli Tengah. Abdimas: Jurnal Pengabdian Masyarakat Universitas Merdeka Malang, 6(3), 475-484. https://doi.org/10.26905/abdimas.v6i3.5322

\section{PENDAHULUAN}

Indonesia merupakan salah satu negara yang kaya akan sumber daya laut dan pesisir, sehingga disebut sebagai negara maritim. Sumber daya laut Indonesia tersebut mencapai 37\% dari spesies ikan di dunia. Perairan laut Indonesia memiliki beberapa jenis ikan bernilai ekonomis penting diantaranya; tuna, cakalang, udang, tongkol, tenggiri, kakap, cumi-cmi, ikan karang, ikan hias, kerang-kerangan dan rumput laut.

Sumber daya laut dan pesisir Indonesia yang tinggi mengantarkan produksi perikanan Indonesia pada Tahun 2004 mencapai 65 juta ton pertahun (Ghufran \& Kordik, 2009). Angka yang demikian 
ABDIMAS: Jurnal Pengabdian Masyarakat Universitas Merdeka Malang Volume 6, No. 3, August 2021: 455-464

dikategorikan tinggi sehingga diindikasikan oleh pemerintah mampu meningkatkan angka pendapatan para nelayan. Diantara banyaknya sumber protein yang tersedia, ikan merupakan salah satu sumber protein yang mudah didapatkan terlebih produksi perikanan Indonesia yang dikategorikan tinggi (Adriani \& Wirjatma, 2012). Persebaran ikan mudah didapatkan dan banyak diperjual belikan oleh para pedagang di pasaran, sehingga memudahkan kita dalam mengkonsumsinya dalam kehidupan sehari-hari.

Mengkonsumsi ikan mampu menambah gizi dalam tubuh manusia sehingga tubuh menjadi lebih sehat. Ikan memiliki gizi tinggi karena mengandung proten yang mengandung asam amino. Asam amino dalam tubuh digunakan untuk membantu proses metabolisme mikroorganisme (Shouchun et al., 2010). Menurut pendapat Idris et al., (2010), bahwa daging ikan mengandung protein, vitamin dan unsur lain yang bermanfaat terhadap tubuh manusia. Ditambahkan oleh Hafiluddin et al. (2014) komposisi kimia dari ikan konsumsi antara lain air (66,0-84,0\%), protein $(15,0-24,0 \%)$, lemak $(0,1-22,0 \%)$ dan mineralmineral $(0,1-2,0 \%)$.

Salah satu faktor yang mempengaruhi status gizi anak adalah kebiasaan makan. Anak cenderung memilih makanan yang disukai dan menyisihkan yang tidak disukai, misalnya jenis sayuran dan ikan. Salah satu zat gizi penting bagi tumbuh kembang anak sekolah adalah protein. Ikan sebagai sumber protein merupakan bahan pangan yang murah, bernilai gizi tinggi dengan kualitas protein yang mudah dicerna serta dapat diolah dengan berbagai macam olahan. Menurut Riyandini et al. (2014), 2/3 kebutuhan protein hewani mampu digantikan oleh adanya potein yang terkandung dalam daging ikan. Ikan juga mengandung lemak yang sangat penting yaitu asam lemak esensial. Asam lemak esensial mampu meningkatkan daya ingat anak ataupun orang dewasa, sehingga disarankan untuk rajin mengkonsumsi daging ikan setiap harinya.

Sejauh ini alasan utama mengapa anak ataupun orang dewasa tidak menyukai ikan untuk dikonsumsi adalah rasa dan aroma amis dari ikan. Menurut Handayani et al. (2020) namun kecenderungan anak-anak mengkonsumsi ikan sangat rendah. Hal ini disebabkan oleh rasa dan aromanya yang kurang menarik, berbeda halnya dengan ayam dan olahannya. Selain itu, menurut Junita \& Dari (2019) Hal ini dapat juga dipengaruhi oleh kondisi ekonomi masyarakat yang rata-rata menengah ke bawah menjadi salah satu faktor rendahnya konsumsi ikan siswa Sekolah Dasar, padahal ketersediaan ikan di lingkungan sekitar cukup. Alasan yang demikian menjadikan rendahnya angka konsumsi ikan khususnya di bangku sekolah. Walaupun ketersediaan ikan sangat tinggi dan mudah untuk didapatkan. Selain alasan diatas, menurut Putri et al. (2015) dan Khomsan (2010) faktor pengetahuan memiliki porsi tersendiri dalam memberikan pengaruh terhadap angka konsumsi ikan. Peningkatan pengetahuan tentang pentingnya konsumsi ikan sangat dibutuhkan agar memberikan dampak yang baik terhadap anak ataupun orang dewasa.

Hasil laporan Nasional Riskesdas tahun 2010 menunjukkan 40,6\% penduduk mengonsumsi makanan di bawah kebutuhan minimal, yaitu kurang dari 70\% Angka Kecukupan Gizi (AKG) yang dianjurkan. Keadaan ini banyak dijumpai pada anak usia sekolah, yaitu sebesar 41,2\% anak sekolah mengonsumsi makanan di bawah kebutuhan minimal. Berdasarkan penelitian ditemukan bahwa terhambatnya pertumbuhan anak disebabkan oleh kurangnya protein yang didapatkan oleh tubuh. 


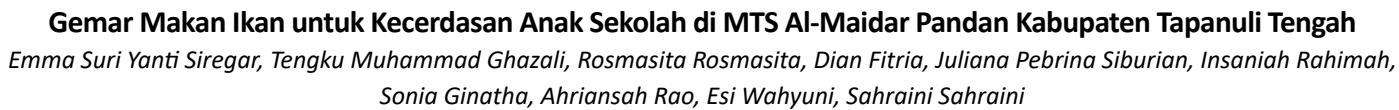

Kurangnya tubuh dalam mendapatkan asupan protein menyebabkan banyak efek negatif terhadap tubuh.

Pangan merupakan kebutuhan dasar manusia yang paling utama. Demi tercapainya sumber daya manusia yang berkualitas diperlukan konsumsi pangan yang bergizi (Prameswari, 2018). Berdasarkan penelitian bahwa ikan merupakan bahan makanan yang sangat mudah untuk membusuk ataupun rusak. Salah satu penyebab membusuknya ikan adalah kandungan air yang terdapat pada dagingnya. Membusuknya ikan dikarenakan mikroorganisme berkembang biak (Astawan, 2004).

Sokib et al. (2012) menyatakan bahwa satu faktor yang paling dominan mempengaruhi konsumen untuk mengkonsumsi ikan, yakni usia. Agar anak gemar makan ikan, diperlukan peningkatan pengetahuan dan sikap anak terkait manfaat positif mengkonsumsi ikan bagi kesehatan, khususnya bagi pertumbuhan dan kecerdasan anak usia sekolah. Sekolah sebagai salah satu media yang efektif untuk mensosialisasikan pentingnya mengkonsumsi ikan untuk kesehatan dan kecerdasan anak,

Kabupaten Tapanuli Tengah yang disingkat Tapteng secara geografis terletak di Pantai Barat Sumatera. Berangkat dari lokasi kabupaten yang dekat dengan laut tentu mendukung masyarakat untuk lebih mudah dalam mendapatkan ikan yang segar. Namun anak sekolah ataupun generasi muda saat ini masih minim angka gemar makan ikan padahal ikan memiliki protein tinggi. Sehingga perlu dilakukan sosialisasi sekaligus mengajak para generasi muda untuk gemar makan ikan untuk meningkatkan kecerdasan anak.

Sosialisasi ini dilaksanakan pada lingkungan sekolah karena sekolah sangat efektif dan mudah untuk dijangkau. Mitra yang dipilih dalam kegiatan pengabdian masyarakat adalah MTs Al-Maidar Pandan. MTs Al-Maidar Pandan merupakan salah satu Madrasah Tsanawiyah yang berada di wiayah Kabupaten Tapanuli Tengah Sumatera Utara. Secara geografis lingkungan MTs Al-Maidar Pandan merupakan daerah yang mudah dalam mendapatkan ikan tetapi anak sekolah pada saat ini masih minim dalam gemar makan ikan.

Sosialisasi tentang gemar makan ikan sudah banyak dilakukan sebagai langkah awal untuk meningkatkan kecerdasan anak, seperti: (1) Bimantara \& Anindita, 2018; (2) Zulfadhli \& Rinawati, 2018; (3) Apriliyanti et al., 2018; (4) Junita \& Dari, 2019; dan (5) Mahrus et al., 2019. Oleh karena itu, tim PKM tertarik untuk melakukan sosialisasi yang bertujuan untuk dapat memunculkan motivasi anak sekolah untuk gemar mengkonsumsi ikan serta meningkatkan pengetahuan siswa/i di Kab. Tapanuli Tengah, maka dilakukan PKM dengan judul "Gemar Makan Ikan Untuk Kecerdasan Anak Sekolah di Kabupaten Tapanuli Tengah" sebagai salah satu langkah meningkatkan gizi anak dengan mengajak anak-anak untuk gemar makan.

\section{METODE}

Kegiatan PKM ini telah dilaksanakan pada tanggal 14 Desember 2020 di salah satu kelas MTS AIMaidar Pandan, Kabupaten Tapanuli Tengah, Provinsi Sumatera Utara. Metode pelaksanaan kegiatan ini adalah pertemuan langsung untuk penyampaian materi oleh narasumber kepada siswa/i yang ada di MTS Al-Maidar Pandan. 
ABDIMAS: Jurnal Pengabdian Masyarakat Universitas Merdeka Malang Volume 6, No. 3, August 2021: 455-464

Bahan-bahan yang digunakan dalam kegiatan ini adalah spanduk, materi presentasi dalam bentuk file power point yang dilengkapi dengan gambar-gambar dan animasi interaktif, media laptop beserta infokus sebagai alat bantu untuk menyampaikan materi, kamera sebagai alat untuk dokumentasi berlangsungnya kegiatan PKM dan souvenir sebagai buah tangan yang diberikan kepada siswa/i.

Sasaran dalam kegiatan ini adalah siswa/siswi kelas VI MTS AI-Maidar Pandan. Pemilihan sasaran dengan kisaran usia 12 tahun dengan alasan lebih komunikatif dan dianggap mampu memahami informasi yang diberikan sehingga dapat memberikan feedback yang ingin diketahui. Total sasaran adalah 30 orang siswa/siswi. Adapun tahapan pelaksanaannya adalah: (1) Dilakukannya survei lokasi pengabdian yaitu di MTS Al-Maidar Pandan Kecamatan Pandan Kabupaten Tapanuli Tengah; (2) Diskusi terkait jadwal pelaksanaan kegiatan dengan kepala sekolah; (3) Menyiapkan surat ijin melaksanakan kegiatan pengabdian; dan (4) Mempersiapkan segala kebutuhan kegiatan seperti bahan dan alat. Kegiatan pengabdian kepada masyarakat yang dilakukan diantaranya: (1) Pembukaan dan perkenalan dengan siswa-siswa di MTS Al-Maidar Pandan Kabupaten Tapanuli Tengah; (2) Penyampaikan materi mengenai pengertian ikan, kandungan gizi ataupun protein ikan, pentingnya makan ikan di MTS AlMaidar Pandan Kabupaten Tapanuli Tengah; dan (3) Diskusi/sharing dengan para siswa-siswa ataupun guru yang ada di sekolah.

Kegiatan juga ditutup dengan beberapa kegiatan seperti: (1) Memberikan buah tangan kepada peserta; (2) Mendokumentasikan kegiatan dengan sesi foto bersama; dan (3) Menuliskan hasil kegiatan yang dituangkan dalam laporan.

\section{HASIL DAN PEMBAHASAN}

Pelaksanaan PKM mengikuti tahapan yang telah disusun karena hal itu merupakan acuan dan sebagai petunjuk teknisnya. Terlaksananya kegiatan dengan baik dan lancar tidak terlepas dari perencanaan yang baik. Perencanaan yang baik akan menghasilkan output yang maksimal. Secara umum mitra yang dipilih dalam kegiatan pengabdian ini sangat antusias menyambut ide yang disampaikan oleh tim pengabdi. Kegiatan Pengabdian Kepada Masyarakat (PKM) yang bertemakan gemar makan ikan dilakukan berdasarkan tahapan-tahapan yang telah direncanakan oleh tim pengabdi.

\section{Persiapan kegiatan}

Sebelum pelaksanaan kegiatan pengabdian kepada masyarakat, terlebih dahulu dilakukan survei ke lokasi dilakukannya pengabdian. Adapun lokasi akan dilaksanakannya kegiatan adalah di MTS AlMaidar Pandan Kecamatan Pandan Kabupaten Tapanuli Tengah. Tujuan survei adalah sebagai bentuk langkah awal apakah sekolah tersebut memiliki kesediaan untuk dijadikan lokasi kegiatan. Kegiatan survei dilakukan untuk memastikan kondisi dan situasi dikarenakan adanya penyebaran COVID-19. Pada masa pandemi siswa/i belum melaksanakan belajar mengajar seperti biasanya, oleh sebab itu perlu dilakukan diskusi dengan pihak sekolah agar pengabdian dapat dilaksanakan.

Survei diawali dengan mengajukan permohonan ijin kepada kepala sekolah serta pengurus sekolah. Pihak sekolah serta para pelaksana PKM menentukan jadwal pelaksanaan kegiatan. Setelah melewati 
proses diskusi didapatkan jadwal pelaksanaan kegiatan. Survei tersebut juga sekaligus melakukan pengurusan administrasi untuk pelaksanaan kegiatan PKM ini, seperti yang terlihat pada Gambar 1.

Setelah melakukan survei langkah selanjutnya adalah mempersiapkan alat serta bahan kegiatan PKM. Diantaranya berupa masker, materi sosialisasi, infokus, rungan serta dilengkapi dengan kursi dan perangkat lainnya yang dapat menunjang terlaksananya kegiatan PKM dengan baik. Kegiatan PKM dilakukan di salah satu ruangan belajar siswa/i. Dalam masa pandemi para pelaksana kegiatan serta pihak sekolah tetap mematuhi protokol kesehatan. Protokol kesehatan disediakan oleh panitia pelaksana seperti masker, cek suhu tubuh, dan hand sanitizer. Protokol kesehatan disediakan agar meminimalisir terjadinya penularan COVID-19 saat berlangsungnya kegiatan nantinya. Tim pengabdi tetap mengindahkan seruan dari pemerintah untuk tetap menjaga kesehatan saat melakukan kegiatan yang mengundang banyak orang. Harapannya dengan mematuhi peraturan para peserta serta tim pengabdi terhindar dari virus tersebut.
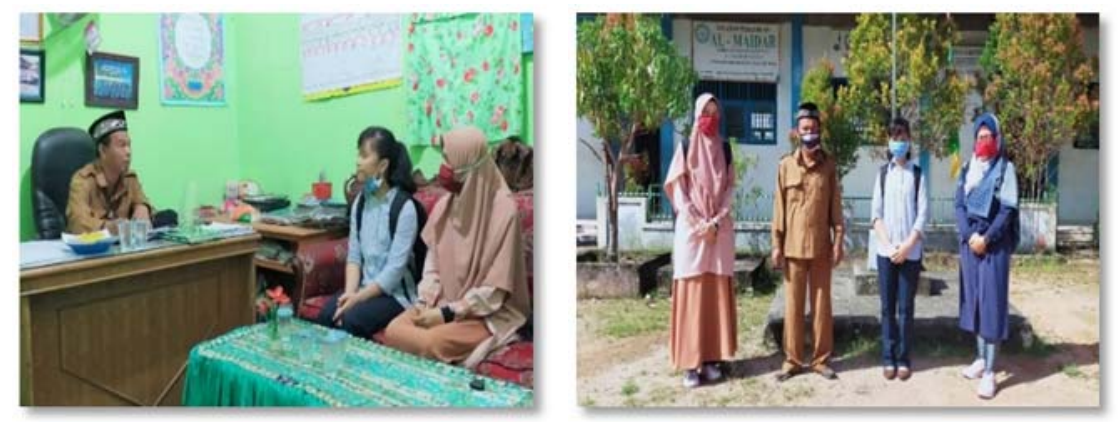

Gambar 1. Survei lokasi PKM

\section{Kegiatan pengabdian}

Pelaksanaan kegiatan PKM dilaksanakan sesuai dengan waktu yang ditentukan oleh kepala sekolah. Setelah semua alat dan bahan dipersiapkan oleh tim pengabdi, selanjutnya pelaksanaan kegiatan pengabdian. Kegiatan pengabdian dimulai dengan melakukan pembukaan acara. Pembukaan acara dibuka oleh salah satu guru yang berada di MTS AI-Maidar Pandan, dan selanjutnya untuk pelaksanaan kegiatan diserahkan secara penuh kepada tim pengabdi. Tim pengabdi selanjutnya melakukan perkenalan diri terlebih dahulu kepada siswa/i sebelum memberikan materi sosialisasi ataupun pengabdian, seperti yang terlihat pada Gambar 2.
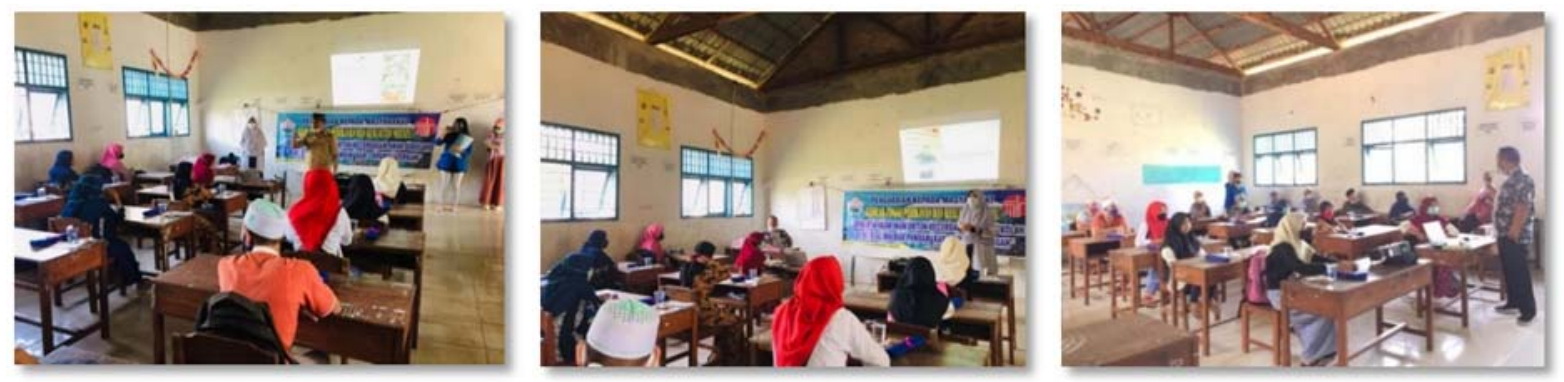

Gambar 2. Pembukaan acara kegiatan PKM oleh guru dan tim pengabdi 
ABDIMAS: Jurnal Pengabdian Masyarakat Universitas Merdeka Malang Volume 6, No. 3, August 2021: 455-464

Perkenalan diri dilakukan sebagai pendahuluan agar para siswa/i mengetahui sedikit informasi mengenai tim pengabdi sekaligus profil pemateri. Tim pengabdi terdiri dari dosen serta mahasiswa. Mahasiswa dan dosen saling berintegrasi dalam menjalankan kegiatan pengabdian ini dengan baik. Mahasiswa diikutsertakan dalam kegiatan pengabdian untuk menambah wawasan serta pengalaman dalam melaksanakan kegiatan serta termotivasi untuk melaksanakan pengabdian yang serupa. Setelah sesi perkenalan maka selanjutnya pemateri memberikan pemaparan serta penjelasan mengenai materi kegiatan. Sebelumnya pemateri telah menyiapkan materi yang akan disampaikan saat kegiatan PKM berlansung, seperti yang terlihat pada Gambar 3. Materi kegiatan disampaikan dengan bantuan infokus serta perangkat komputer lainnya. Materi yang disampaikan meliputi pengertian ikan, kandungan gizi ataupun protein ikan, manfaat mengonsumsi ikan dan informasi lainnya yang dianggap menambah pengetahuan dan wawasan para peserta pengabdian.

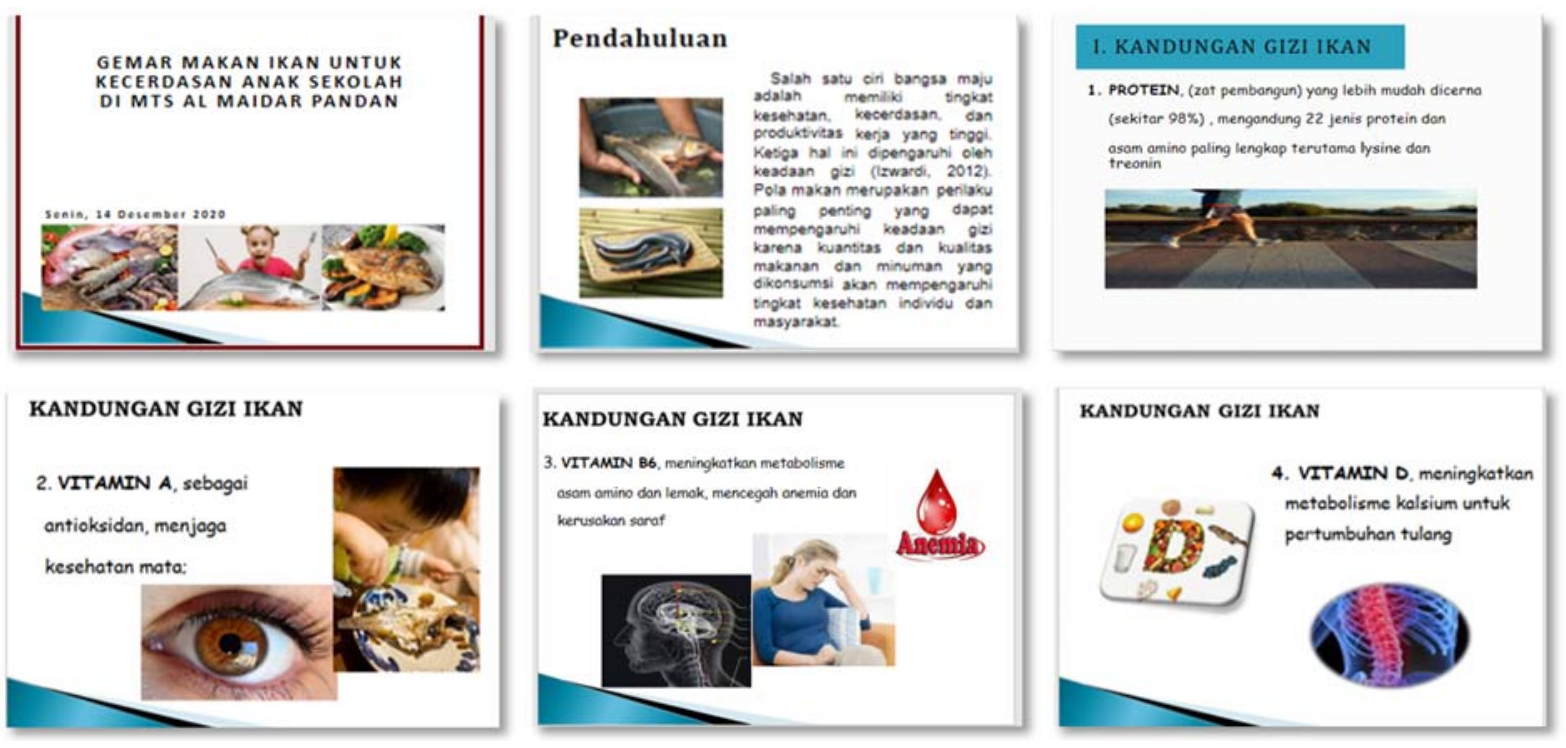

Gambar 3. Penyampaian materi oleh tim pengabdi serta cuplikan materinya

Acara selanjutnya setelah penyampaian materi yaitu sesi tanya jawab dengan peserta pengabdian. Berdasarkan analisa, para siswa/i sangat antusias untuk mengikuti kegiatan, dapat dilihat dari banyaknya pertanyaan yang diajukan kepada pemateri. Pada sesi diskusi peserta mengajukan pertanyaan dan kemudian diberikan penjelasan oleh pemateri mengenai pertanyaan tersebut, seperti yang terlihat pada Gambar 4.
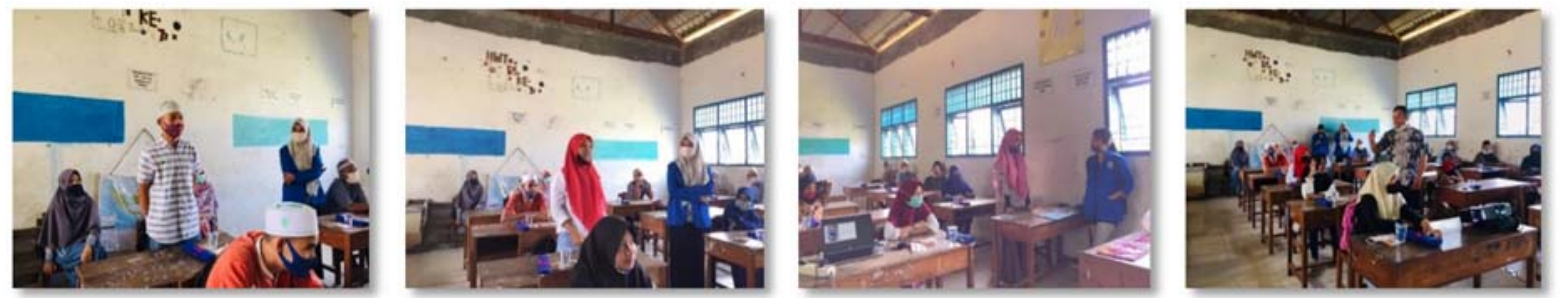

Gambar 4. Sesi tanya jawab oleh peserta kegiatan 


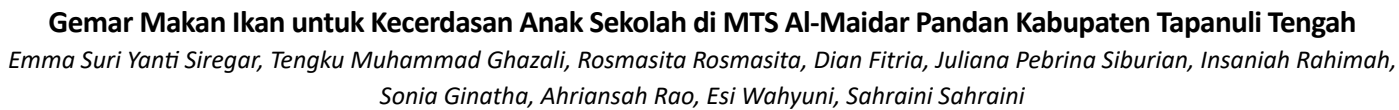

\section{Penutupan}

Penyampaian materi pengabdian telah dilakukan, tahap selanjutnya dari kegiatan pengabdian kepada masyarakat adalah penutupan. Pada sesi penutupan tim pengabdi memberikan apresisasi berupa pemberian penghargaan bagi peserta yang memiliki keberanian untuk mengajukan pertanyaan kepada pemateri. Hal itu dilakukan sebagai bentuk apresiasi telah antusias mengikuti kegiatan pengabdian dengan baik.

Kegiatan selanjutnya yaitu pengambilan gambar sebagai dokumentasi kegiatan, sekaligus berpamitan dengan kepala sekolah, para guru serta siswa/i MTS Al-maidar Pandan. Pihak sekolah sangat antusias dalam mensukseskan kegaitan pengabdian, dapat dibuktikan dengan partisipasi pihak sekolah dalam ikut serta mempersiapkan kegiatan. Pihak sekolah memiliki kesan yang baik terhadap kegiatan tersebut dikarenakan dapat menambah ilmu pengetahuan serta wawasan para siswa/i MTS Al-maidar Pandan mengenai ikan serta manfaatnya apabila dikonsumsi, seperti yang terlihat pada Gambar 5.
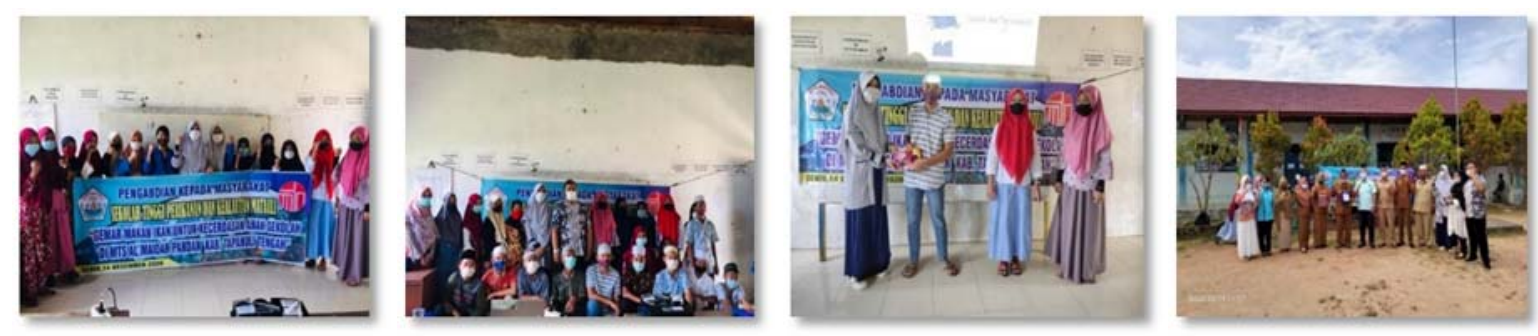

Gambar 5. Penutupan kegiatan pengabdian kepada masyarakat

\section{Output dan outcome}

Output kegiatan pengabdian kepada masyarakat ini adalah: (1) Peserta diberikan wawasan tentang manfaat serta kandungan gizi yang terdapat pada ikan kepada siswa dan mampu membedakan yang mana ikan busuk maupun ikan segar; (2) Dari hasil penyuluhan gemar makan ikan, para siswa/i memahami pentingnya mengonsumsi ikan untuk kecerdasan anak dan dapat membedakan kualitas ikan baik untuk dikonsumsi; dan (3) Sesi pertanyaan dibuka untuk melihat pemahaman peserta tentang isi materi. Siswa/i yang berani bertanya berhak memperoleh hadiah sebagai bentuk apresiasi.

Outcome kegiatan PKM adalah: (1) Sosialisasi kegiatan gemar makan ikan diharapkan dapat meningkatkan pengetahuan dan informasi mengenai manfaat serta kandungan gizi ikan kepada siswa serta dapat membedakan yang mana ikan busuk maupun ikan segar; (2) Kegiatan gemar makan ikan ini harapannya semoga dapat memberi dampak positif kepada siswa/i tentang pentingnya mengkonsumsi ikan yang dapat membantu meningkatkan kecerdasan anak; dan (3) STPK Matauli yang menjalankan program studi bidang perikanan dan kelautan memiliki keterkaitan langsung dengan masyarakat sehingga memiliki kepedulian dalam mengajak masyarakat untuk gemar makan ikan demi kecerdasan anak.

\section{Deskripsi proses kegiatan}

Kegiatan gemar makan di MTS Al-Maidar Pandan terlaksana dengan baik dan lancar. Para siswa/i serta guru membantu mempersiapkan tempat untuk pelaksanaan sosialisasi/penyuluhan. 
ABDIMAS: Jurnal Pengabdian Masyarakat Universitas Merdeka Malang Volume 6, No. 3, August 2021: 455-464

Peserta merupakan siswa/i yang ada di MTS Al-Maidar Pandan Kabupaten Tapanuli Tengah. Tempat kegiatan gemar makan ikan dilaksanakan dikelas. Pelaksanaan kegiatan sosialisasi gemar makan ikan menggunakan alat infokus dan laptop sebagai media penyampaian.

Sebelum melakukan kegiatan sosialisasi tentang gemar makan ikan, pemateri memperkenalkan diri terlebih dahulu kemudian mencoba menggali pengetahuan dasar siswa/i berkaitan dengan wawasan seputar ikan dan kandungan gizi yang terdapat pada ikan. Pematerimengajukan beberapa pertanyaan mengenai pengertian ikan dan manfaatnya terhadap manusia. Setelah menggali pengetahuan dasar, pemateri memaparkan definisi dari ikan, manfaat serta kandungan gizi yang terdapat pada ikan. Dalam penyampaikan materi, pemateri dibantu dengan materi presentasi dalam bentuk file power point yang dilengkapi dengan gambar-gambar dan animasi interaktif untuk menambah minat siswa/i dalam mengikuti sosialisasi gemar makan ikan. Kegiatan kemudian dilanjutkan dengan penyuluhan akan pentingnya mengonsumsi ikan untuk kecerdasan anak. Manfaat yang diperoleh oleh siswa/i setelah mengikuti sosialisasi bukan hanya mengetahui tentang pengertian ikan, kandungan gizi pada ikan, akan tetapi siswa/i nantinya akan mengetahui cara membedakan ikan yang layak dan tidak layak untuk dikonsumsi.

Sosialisasi gemar makan ikan dilaksanakan kurang lebih sekitar 60 menit. Diakhir pelaksanaan sosialisasi ini dilakukan sesi tanya jawab dengan para peserta guna memberikan wawasan yang lebih dalam tentang materi yang dipaparkan oleh pemateri. Jika dirangkum kurang lebih pertanyaan berjumlah sekitar 3 dari penanya yang berbeda-beda. Sesi ini merupakan bentuk evaluasi terhadap suksesnya pelaksanaan kegiatan sosialisasi.

Di akhir kegiatan diberikan penghargaan terhadap siswa/i yang memiliki keberanian untuk bertanya. Hal ini diharapkan menjadi motivasi untuk para siswa agar lebih percaya diri dalam menggali ilmu pengetahuan khususnya dilingkungan sekolah. Selanjutnya untuk menutup kegiatan sosialisasi gemar makan ikan, dilakukan sesi foto bersama dengan para siswa/i peserta sosialisasi, para guru, panitia serta pemateri sebagai bentuk dokumentasi terlaksananya kegiatan ini dengan baik dan lancar.

\section{Evaluasi}

Peningkatan hasil kegiatan pangabdian kepada masyarakat sangat diperlukan. Oleh sebab itu perlu dilakukan evaluasi terhadap kegiatan pengabdian yang sudah terlaksana. Evaluasi dilakukan dengan melihat sejauh mana para peserta mampu menyerap ilmu dan pengetahuan yang telah dipaparkan oleh pemateri. Selain itu, evaluasi selanjutnya diliat dari persiapan alat dan bahan serta teknis pelaksanaanya. Pelaksanaan PKM ini telah terlaksana dengan baik dapat dilihat dari banyaknya siswa/i yang antusias mengikuti sesi tanya jawab, mengikuti kegiatan dengan baik hingga akhir kegiatan serta berharap adanya penyuluhan mengenai gemar makan ikan yang dilaksana secara berkelanjutan. Sebagai bahan evaluasi untuk meningkatkan hasil kegiatan, tim pengabdi akan melakukan perencanaan yang lebih maksimal untuk kegiatan selanjutnya. 


\section{SIMPULAN DAN SARAN}

Sosialisasi kegiatan gemar makan ikan di MTS AI-Maidar Pandan Kecamatan Pandan Kabupaten Tapanuli Tengah bertujuan untuk meningkatkan pengetahuan anak sekolah yang merupakan salah satu langkah dalam meningkatkan gizi anak serta dapat memunculkan motivasi anak sekolah untuk gemar mengkonsumsi ikan. Sosialisasi ini terlaksana dengan baik, peserta antusias dan berharap adanya penyuluhan mengenai gemar makan ikan yang dilaksana secara berkelanjutan. Siswa/i juga menyampaikan harapan untuk program selanjutnya dilaksanakan secara merata disemua kelas yang ada di MTS Al-Maidar Pandan.

Terlaksananya kegiatan PKM mengantarkan penulis untuk memberikan saran sebagai berikut: (1) Kegiatan sosialisasi gemar makan ikan sebaiknya dilaksanakan secara kontinu untuk menambah wawasan dan ilmu siswa/i baik taraf SD, SMP ataupun SMA; (2) Kegiatan pengabdian seperti ini juga dapat dilakukan di lokasi yang berbeda dengan sasaran siswa/i agar memiliki pengetahuan tentang kandungan gizi dan serta manfaat mengonsumsi ikan; (3) Kegiatan pengabdian perlu dilakukan pemantauan dalam implementasi konsumsi ikan pada anak sekolah; dan (4) Kegiatan pengabdian perlu dikaji peran dan dukungan keluarga dalam mewujudkan manfaat konsumsi ikan pada anak.

\section{UCAPAN TERIMA KASIH}

Penulis menyampaikan terima kasih kepada Yayasan Maju Tapian Nauli (MATAULI) serta Ketua Sekolah Tinggi Perikanan dan Kelautan Matauli (STPK Matauli) yang telah mendukung penyelenggaraan kegiatan pengabdian ini, dan kepada Mitra yaitu MTS Al-Maidar Pandan atas kesediaan dan partisipasi aktif siswa/i beserta para guru untuk terselenggaranya kegiatan ini.

\section{DAFTAR PUSTAKA}

Adriani, M., \& Wirjatmadi, B. (2012). Peran Gizi dalam Siklus Kehidupan. Kencana Prenada Media Group.

Astawan, M. (2004). Ikan yang Sedap dan Bergizi. Tiga Serangkai.

Bimantara, A., \& Anindita, N. S. (2018). Gerakan memasyarakatkan makan ikan sejak usia dini melalui pelatihan pengolahan ikan bagi orang tua siswa kelas I SD Muhammadiyah Wirobrajan 3 Yogyakarta. Jurnal Pengabdian Masyarakat MIPA dan Pendidikan MIPA, 2(2), 72-77.

Junita, D., \& Dari, D. W. 2019). PKM Gemar makan ikan untuk kecerdasan anak sekolah di SDN 82/Iv Sejinjang Kota Jambi. Jurnal Abdimas Kesehatan, 1(1), 6-11. https://doi.org/10.36565/jak.v1i1.3

Prameswari, G. N. (2018). Promosi gizi terhadap sikap gemar makan ikan pada anak usia sekolah. Journal of Health Education, 3(1), 1-6.

Hafiluddin, H., Perwitasari, Y., \& Budiarto, S. (2014). Analisis kandungan gizi dan bau lumpur Ikan Bandeng (Chanos chanos) dari dua lokasi yang berbeda. Jurnal Kelautan: Indonesian Journal of Marine Science and Technology, 7(1), 33-44. 
ABDIMAS: Jurnal Pengabdian Masyarakat Universitas Merdeka Malang Volume 6, No. 3, August 2021: 455-464

Idris, G. L., Omojowo, F. S., Omojasola, P. F., Adetunji, C. O., \& Ngwu, E. O. (2010). The effect of different concentrations of ginger on the quality of smoked dried catfish (Clarias gariepinus). Nature and Science, 8(4), 59-63.

Khomsan, A. (2010). Pangan dan Gizi Untuk Kesehatan. Rajagrafindo Persada.

Shouchun, L., Wen, F., Saiyi, Z., Changwei, M., Pinglan, L., Kang, Z., ... Meijun, Z. (2010). Quality evaluation of tray-packed tilapia fillets stored at $0^{\circ} \mathrm{C}$ based on sensory, microbiological, biochemical and physical attributes. African Journal of Biotechnology, 9(5), 692-701. https://doi.org/10.5897/ajb09.1369

Mahrus, Zulkifli, L., Rasmi, D. A. C., Sedijani, P., \& Bahri, S. (2019). Penyuluhan gerakan makan ikan laut sebagai upaya peningkatan gizi Di SMPN 2 Gunungsari Kabupten Lombok Barat. Jurnal Pengabdian Magister Pendidikan IPA, 1(2), 17-21. https://doi.org/10.29303/jpmpi.v1i2.241

Apriliyanti, M. W., Brilliantina, A., \& Sari, E. K. N. (2018). Sosialisasi GEMARIKAN (Gerakan Makan Ikan) dan pelatihan diversifikasi produk olahan ikan SDIT Harapan Umat, Kecamatan Sumbersari, Kabupaten Jember. Prosiding Seminar Nasional Hasil Penelitian dan Pengabdian Masyarakat. Jawa Timur, 117-121.

Riyandini, M. C., Sudaryati, E., \& Siagian, A. (2014). Hubungan konsumsi ikan dengan prestasi belajar anak di Sekolah Dasar Swasta Brigjend Katamso II Kecamatan Medan Marelan Kota Medan. Jurnal Gizi, Kesehatan Reproduksi dan Epidemiologi, 1(4).

Putri, A.M., Jumirah, \& Siagian, A. (2015). Faktor-faktor yang berhubungan dengan pola konsumsi ikan siswa Sekolah Dasar Negeri 060919 di Kecamatan Medan Sunggal. Jurnal Gizi, Kesehatan Reproduksi dan Epidemiologi, 1(5).

Zulfadhli, Z., \& Rinawati. (2018). Sosialisasi Gerakan Memasyarakatkan Makan Ikan (Gemarikan) pada siswa sekolah dasar di Aceh Barat. Jurnal Marine Kreatif, 2(1), 39-43. https://doi.org/10.35308/jmk.v2i1.2273

Sokib, N., Palupi, N. S., \& Suharjo, B. (2012). Strategi peningkatan konsumsi ikan di Kota Depok, Jawa Barat. MANAJEMEN IKM: Jurnal Manajemen Pengembangan Industri Kecil Menengah, 7(2), 166171. 